\title{
Galactomannan Testing for Early Diagnosis of Exserohilum rostratum Infection
}

\author{
Maya Korem, Itzhack Polacheck, Ayelet Michael-Gayego, Jacob Strahilevitz \\ Department of Clinical Microbiology and Infectious Diseases, Hadassah-Hebrew University Medical Center, Jerusalem, Israel
}

$E^{\mathrm{s} i n}$ xserohilum rostratum is the most common pathogen in the tion, septic arthritis, and localized spinal or paraspinal infections (1). Rapid laboratory diagnosis is urgently needed but is unfortunately still limited. Only $30 \%$ of the 372 case patient specimens sent to the Centers for Disease Control and Prevention (CDC) had PCR evidence supportive of fungal infection $(1,2)$. The $\beta$-D-glucan assay, which can detect $(1,3)-\beta$-D-glucan, a major cell wall component of many fungi, was useful in culture-independent diagnosis of three patients who were potentially exposed to contaminated methylprednisolone and presented with findings suggestive of fungal central nervous system infection (3). The assay, however, has not been approved by the U.S. Food and Drug Administration (FDA) for use on cerebrospinal fluid (CSF) samples.

Galactomannan is a major constituent of Aspergillus cell walls that is released during growth and can be detected by an FDAapproved immunoassay (4). Positive serum galactomannan antigen has also been reported during invasive infections by other fungi, such as Penicillium, Alternaria, Paecilomyces, Histoplasma, Geotrichum, Fusarium, and Cryptococcus species (5-10). We present a case of Exserohilum rostratum infection in which the serum galactomannan assay facilitated early diagnosis. A 44-year-old male with acute lymphoblastic leukemia who underwent allogeneic stem cell transplantation developed necrotic lesions in the nose and maxillary sinus. Biopsy showed angioinvasive brownpigmented septate hyphae, and the culture was identified morphologically and by intergenic transcribed spacer (ITS) region and $28 \mathrm{~S}$ ribosomal DNA sequences as Exserohilum rostratum. Treatment with intravenous amphotericin B deoxycholate at $1.5 \mathrm{mg} / \mathrm{kg}$ of body weight/day resulted in clinical improvement, and recovery followed engraftment. The serum galactomannan test was positive at presentation, thus driving early detection of invasive fungal disease. Galactomannan levels declined slowly under treatment (Table 1) but remained positive after neutrophil recovery. At the time of serum sample collection, the patient did not receive antibiotics, such as piperacillin-tazobactam, amoxicillin-clavulanate, or gluconate-containing Plasma-Lyte solutions, that could have caused false positivity in the galactomannan assay $(11,12)$.

The clinical isolate was tested in vitro for galactomannan content. Fresh inocula of $10^{4}$ spores per $\mathrm{ml}$ were grown overnight at $30^{\circ} \mathrm{C}$ in YPD broth medium (yeast extract-peptone-dextrose, 2:2:2 g/liter) on a rotary shaker. Fungal suspensions in phosphatebuffered saline $(\mathrm{PBS})$ were extracted by centrifugation $(2,000 \times g)$ followed by filtration $(0.2 \mu \mathrm{m}$ pore size $)$. The filtrates were tested for galactomannan (Platelia Aspergillus antigen [Ag] kit; Bio-Rad Laboratories, Inc., Hercules, CA, USA) after appropriate dilution with saline. The Exserohilum rostratum isolate yielded a positive test, with a galactomannan content comparable to that of an Aspergillus fumigatus positive control (Table 1). Testing galactomannan in serum and CSF is recommended for the diagnosis of
TABLE 1 Galactomannan levels in serum and fungal extracts

\begin{tabular}{lll}
\hline & \multicolumn{2}{l}{$\begin{array}{l}\text { Galactomannan } \mathrm{ODI}^{a} \text { for } \\
\text { sample with: }\end{array}$} \\
\cline { 2 - 3 } Sample & No dilution & $10^{-3}$ dilution \\
\hline Serum & & \\
$\quad$ Upon diagnosis & 2.25 \\
$\quad$ After 2 wk of treatment & 1.5 & \\
After 3 wk of treatment & 0.95 & \\
4 wk following neutrophil recovery & 0.52 & \\
Fungal extract & & 2.01 \\
$\quad$ Exserohilum rostratum (our case) & 5.08 & 1.85 \\
$\quad$ Aspergillus fumigatus (ATCC 64026) & 5.02 & \\
\hline
\end{tabular}

${ }^{a}$ ODI, optical density index.

invasive aspergillosis $(13,14)$. Although our observation is based on a single case, it suggests that the widely available galactomannan assay, applied to CSF, warrants evaluation as an aid in the early detection of Exserohilum rostratum infection in the current epidemic.

\section{REFERENCES}

1. Smith RM, Schaefer MK, Kainer MA, Wise M, Finks J, Duwve J, Fontaine E, Chu A, Carothers B, Reilly A, Fiedler J, Wiese AD, Feaster C, Gibson L, Griese S, Purfield A, Cleveland AA, Benedict K, Harris JR, Brandt ME, Blau D, Jernigan J, Weber JT, Park BJ, Multistate Fungal Infection Outbreak Response Team. 19 December 2012. Fungal infections associated with contaminated methylprednisolone injectionspreliminary report. N. Engl. J. Med. [Epub ahead of print.] doi:10.1056 /NEJMoa1213978.

2. Kainer MA, Reagan DR, Nguyen DB, Wiese AD, Wise ME, Ward J, Park BJ, Kanago ML, Baumblatt J, Schaefer MK, Berger BE, Marder EP, Min JY, Dunn JR, Smith RM, Dreyzehner J, Jones TF. 2012. Fungal infections associated with contaminated methylprednisolone in Tennessee. N. Engl. J. Med. 367:2194-2203.

3. Lyons JL, Roos KL, Marr KA, Neumann H, Trivedi JB, Kimbrough DJ, Steiner L, Thakur KT, Harrison DM, Zhang SX. 2013. Cerebrospinal fluid $(1,3)$ - $\beta$-D-glucan detection as an aid for diagnosis of iatrogenic fungal meningitis. J. Clin. Microbiol. 51:1285-1287.

4. Maertens J, Theunissen K, Lodewyck T, Lagrou K, Van Eldere J. 2007. Advances in the serological diagnosis of invasive Aspergillus infections in patients with haematological disorders. Mycoses 50(Suppl 1):S2-S17.

5. Cummings JR, Jamison GR, Boudreaux JW, Howles MJ, Walsh TJ, Hayden RT. 2007. Cross-reactivity of non-Aspergillus fungal species in the Aspergillus galactomannan enzyme immunoassay. Diagn. Microbiol. Infect. Dis. 59:113-115.

6. Swanink CM, Meis JF, Rijs AJ, Donnelly JP, Verweii PE. 1997. Speci-

Published ahead of print 29 May 2013

Address correspondence to Maya Korem, mayak@hadassah.org.il.

Copyright $\odot$ 2013, American Society for Microbiology. All Rights Reserved.

doi:10.1128/JCM.00955-13 
ficity of a sandwich enzyme-linked immunosorbent assay for detecting Aspergillus galactomannan. J. Clin. Microbiol. 35:257-260.

7. Wheat LJ, Hackett E, Durkin M, Connolly P, Petraitiene R, Walsh TJ, Knox K, Hage C. 2007. Histoplasmosis-associated cross-reactivity in the BioRad Platelia Aspergillus enzyme immunoassay. Clin. Vaccine Immunol. 14:638-640.

8. Giacchino M, Chiapello N, Bezzio S, Fagioli F, Saracco P, Alfarano A, Martini V, Cimino G, Martino P, Girmenia C. 2006. Aspergillus galactomannan enzyme-linked immunosorbent assay cross-reactivity caused by invasive Geotrichum capitatum. J. Clin. Microbiol. 44:3432-3434.

9. Mikulska M, Furfaro E, Del Bono V, Gualandi F, Raiola AM, Molinary MP, Gritti P, Sanguinetti M, Posteraro B, Bacigalupo A, Viscoli C. 2012. Galactomannan testing might be useful for early diagnosis of fusariosis. Diagn. Microbiol. Infect. Dis. 72:367-369.

10. Dalle F, Charles PE, Blanc K, Caillot D, Chavanet P, Dromer F, Bonnin A. 2005. Cryptococcus neoformans Galactoxylomannan contains an epitope(s) that is cross-reactive with Aspergillus galactomannan. J. Clin. Microbiol. 43:2929-2931.

11. Aubry A, Porcher R, Bottero J, Touratier S, Leblanc T, Brethon B, Rousselot P, Raffoux E, Menotti J, Derouin F, Ribaud P, Sulahian A. 2006. Occurrence and kinetics of false-positive Aspergillus galactomannan test results following treatment with beta-lactam antibiotics in patients with hematological disorders. J. Clin. Microbiol. 44:389-394.
12. Petraitiene R, Petraitis V, Witt JR, III, Durkin MM, Bacher JD, Wheat LJ, Walsh TJ. 2011. Galactomannan antigenemia after infusion of gluconate-containing Plasma-Lyte. J. Clin. Microbiol. 49:4330-4332.

13. De Pauw B, Walsh TJ, Donnelly JP, Stevens DA, Edwards JE, Calandra T, Pappas PG, Maertens J, Lortholary O, Kauffman CA, Denning DW, Patterson TF, Maschmeyer G, Bille J, Dismukes WE, Herbrecht R, Hope WW, Kibbler CC, Kullberg BJ, Marr KA, Muñoz P, Odds FC, Perfect JR, Restrepo A, Ruhnke M, Segal BH, Sobel JD, Sorrell TC, Viscoli C, Wingard JR, Zaoutis T, Bennett JE, European Organization for Research and Treatment of Cancer/Invasive Fungal Infections Cooperative Group National Institute of Allergy and Infectious Diseases Mycoses Study Group Consensus Group. 2008. Revised definitions of invasive fungal disease from the European Organization for Research and Treatment of Cancer/Invasive Fungal Infections Cooperative Group and the National Institute of Allergy and Infectious Diseases Mycoses Study Group (EORTC/MSG) Consensus Group. Clin. Infect. Dis. 46:18131821.

14. Marchetti O, Lamoth F, Mikulska M, Viscoli C, Verweij P, Bretagne S, European Conference on Infections in Leukemia (ECIL) Laboratory Working Groups. 2012. ECIL recommendations for the use of biological markers for the diagnosis of invasive fungal diseases in leukemic patients and hematopoietic SCT recipients. Bone Marrow Transplant. 47:846854. 